\title{
The Model of Local Regulation of the Human Rights Fulfillment Based on Progressive Law
}

\author{
Yulia Neta ${ }^{1}$ \\ Budiyono $^{2}$ \\ Ade Arif Firmansyah ${ }^{3}$
}

\begin{abstract}
${ }^{1}$ Faculty of Law, Universitas Lampung, Indonesia. E-mail: yulia.neta@fh.unila.ac.id
2 Faculty of Law, Universitas Lampung, Indonesia. E-mail: budiyono1974@fh.unila.ac.id

${ }^{3}$ Faculty of Law, Universitas Lampung, Indonesia. E-mail: ade.firmansyah@fh.unila.ac.id
\end{abstract}

\section{Article Info}

Keywords:

Local Regulation;

Human rights;

Progressive law.

How to cite (APA Citation Style):

Neta, Y., Budiyono., Firmansyah, A.A. (2021).

"The Model of Local Regulation of the Human Rights Fulfillment Based on Progressive Law". Jambura Law Review. JALREV 3 Special Issue: $1-16$

\begin{abstract}
This paper is aimed for analyzing and creating the model for the Content of Regional Regulations on Fulfillment of Human Rights Based on Progressive Law. The material model for the content of the Local regulation Fulfillment of Human Rights based on progressive law relies on three things, namely: laws and regulations that regulate human rights both vertically and horizontally, the contextual reality of the recognition and protection of human rights found in local communities and thirdly for humans and humanity. Systematically, the division of chapters containing the content in it consists of: general provisions; principles and objectives; type of human rights; human rights recognition; protection of human rights; fulfillment of human rights; community participation; guidance and supervision; funding and closing provisions. By using the socio-legal approach, this paper describes the material model for the content of regional regulations regarding the fulfillment of human rights based on progressive law.
\end{abstract}

(C) 2021 - Neta, Y., Budiyono, Firmansyah, A.A.

Under the license CC BY-SA 4.0 


\section{Introduction}

The Republic of Indonesia which is based on Pancasila and the 1945 Indonesia Constitution respects and upholds human dignity. ${ }^{4}$ Indonesia in the constitution is a rule of law, ${ }^{5}$ the manifestation of which is reflected in the laws and regulations designed to limit the power of the state (government) and provide guidelines for the people in carrying out their activities as citizens. 6 One of the materials for the amendment of the 1945 Constitution is the guarantee of human rights and constitutional rights of citizens. This change can be seen as a manifestation of awareness about the importance of protecting the human rights and constitutional rights of citizens, which grows and becomes the spirit of reform. Similar guarantees have also been formulated in the People's Consultative Assembly Decree Number XVII/ MPR/ 1998 concerning Human Rights which later became material for Law Number 39 of 1999 concerning Human Rights, before finally being outlined in the Amendment to the 1945 Indonesian Constitution. Citizens' constitutional rights guaranteed in the 1945 Indonesian Constitution covering various aspects of life, whether civil, political, economic, or social.

During the last few years, the concept of Human Rights Cities has become a very hot topic when the public talks about protecting and fulfilling citizens' human rights, eradicating corruption, preventing intolerance and reducing inequality. This concept is so popular, that in his speech to commemorate World Human Rights Day 2015, President Jokowi expressed his appreciation and called for multiplication in the implementation of the concept of a Human Rights City/ district. The President said that the protection and fulfillment of human rights is not solely the responsibility of the central government, but also the regional government. Human Rights City/ district was originally a movement to ground human rights at the local level. The adoption of a human rights district/ city is justified by the responsibility of the government, both central and/ or local, to protect, fulfill and respect human rights.

\footnotetext{
General Explanation of Law No. 8 of 2016 on Persons with Disabilities

Novendri M. Nggilu and Fence M. Wantu. (2020). Menapaki Jalan Konstitusional Menuju Zaken Cabinet: Ikhtiar Mewujudkan Pemerintah Berkualitas Konstitusi.Jurnal Hukum Samudra Keadilan, 15(1), 126-140. p. 139

6 Nuvazria Achir. (2020). " Anotasi Normatif Terhadap Peraturan Daerah Tentang Transparansi". Jambura Law Review, JALREV 2 (1): 83-100. p. 85.
} 
Local regulation on Fulfillment of Human Rights is very important in mainstreaming human rights as a reference in planning and implementing development in the regions. Local governments that mainstream human rights in regional development encourage the promotion, protection and fulfillment of human rights. This Local regulation on Fulfillment of Human Rights is also to address the current sociopolitical conditions which show the strengthening of intolerance that has the potential to destroy diversity and erode the solidarity of citizens as a nation.

The shift of power to the regions (regional autonomy) actually also has an impact on the stronger authority of the regional government to emphasize respect, protection and fulfillment of human rights. However, like two sides of a coin, it can also result in a higher potential for human rights violations. Human Rights National Committee complaint data has proven that for the past 5 years or so, the Regional Government has always been in the top three parties who were complained of committing acts that indicated human rights violations. ${ }^{7}$

\section{Problem Statement}

Local governments have a key role in fulfilling, protecting and respecting human rights. The development of human rights cannot depend solely on the central government. The role of the regional government is needed to be able to spread the issue of protection, respect and fulfillment of human rights based on progressive law as the basis. Based on this reality, research is needed that will formulate the Material Model of Regional Regulations on Fulfillment of Human Rights based on Progressive Law, in order to facilitate local governments in drafting Regional Regulations on Fulfilling Human Rights.

Based on the background that has been described, the problem formulations in this paper about the Material Model for the Content of Regional Regulations on Fulfillment of Human Rights Based on Progressive Law

7 Human right National Commission. (ed. January 8, 2016). "Human rights friendly cities in Indonesia". Retrieved from https://www.komnasham.go.id/index.php/news/2016/1/8/245/mendorong-kota-ramah-ham-diindonesia.html. Accessed on February 10, 2020. 


\section{Method}

The approach used in this paper is a socio-legal, which concepting law is not limited to the norm, but also as a behavior. Conception of law as behavior that appears in reality have consequence that the law is seen not just as a suitable concrete, written, contains the sanctions and issued by competent authorities that in operation is influenced by many other factors such as economics, politics, culture, religion, and etc. ${ }^{8}$

The use of this approach is important to bring it to a more thorough understanding of the law, intact and not text only. Also want to known whether the regulation is effective, positive, productive, or even disturb and ruin. ${ }^{9}$ Some data are obtained through the website. The data is combined with an overview of the legislation. The analysis was performed by using descriptive-qualitative method.

\section{Discussion}

\subsection{State, Local Government and Human Rights}

Modern democracies assume the formation of states based on social treaty theory. Based on this theory, the purpose of establishing a state is to protect and fulfill the rights of its citizens. According to Thomas Hobbes social agreement theory, the function of the state is to protect the rights of citizens so that there is no violation of the rights of one citizen against another citizen. Therefore, the protection and fulfillment of citizens' rights are at the core of the rule of law conception. All legal norms that form the basis of state administration must be oriented towards protecting and fulfilling the rights of citizens. In the practice of implementing a rule of law, legal instruments and institutions are needed to protect and guarantee the protection and fulfillment of citizens' rights. These legal instruments and institutions are the characteristics of a rule of law, which have developed both in the civil law tradition with the rechtsstaat concept and in the common law tradition with the concept of the rule of law.

8 FX. Adji Samekto. (2012), "Ilmu Hukum dalam Perkembangan Pemikiran Menuju Post-Modernisme". Lampung: Indept Publishing. p. 73.

9 Brian Z. Tamanaha. (2006). "A General Jurisprudence of Law and Society”. Oxford: Oxford University Press. p. 1-2. 
Law No. 23 of 2014 concerning Regional Government gives the meaning of Regional Government is the implementation of government affairs by the regional government and regional people's representative council according to the principle of autonomy and duty of assistance with the broadest possible autonomy principle in the system and principles of the Unitary State of the Republic of Indonesia as referred to in the Constitution of the State. The Republic of Indonesia in 1945. The implementation of regional government according to the principle of autonomy means that the regional government has the rights, powers and obligations of the autonomous region to regulate and manage their own Government Affairs and interests of the local community in the Unitary State system. ${ }^{10}$ The decentralization of authority can be referred to as the decentralization of responsibility for fulfilling human rights to all regions. Therefore, the three phases of change must be understood by the regions as a form of delegation of authority to regulate and fulfill human rights. ${ }^{11}$

The United Nations stated that the main challenge for regional governments in protecting and advancing human rights is the existence of political, economic and administrative will. These challenges include weaknesses related to institutional capacity and resources, whether due to a lack of political will or a lack of economic resources. Other challenges include a lack of coordination between the Central and Local Governments, a lack of information on human rights at the local level, and a lack of recognition of the role and contribution of civil society in the protection and promotion of human rights. ${ }^{12}$

Along with the development of autonomy by the regional government, it is necessary to recognize, protect and supervise human rights by the regional government. 13 Therefore, the formation and formulation of policies by the regional government in the form of Regional Regulations and other regional policies must not conflict with

10 Frichy Ndaumanu. (2018). "Kebijakan Pemerintah Daerah Terhadap Upaya Perlindungan Dan Penghormatan Masyarakat Hukum Adat Di Kabupaten Alor Provinsi Nusa Tenggara Timur". Jurnal HAM Vol. 9 (1) July: 37-49.

11 Al Khanif, dkk. (2019). "Kajian Tentang Model Rencana Aksi Daerah Hak Asasi Manusia (RADHAM) Kabupaten Bondowoso Tahun 2018”. Jurnal Hukum \& Pembangunan 49 (2): 425-442. p. 426.

12 Al Khanif, dkk,. (2019). "Kajian Tentang Model Rencana Aksi Daerah Hak Asasi Manusia (RADHAM) Kabupaten Bondowoso Tahun 2018”. Jurnal Hukum \& Pembangunan 49 (2): 425-442. p. 426.

13 Faisal A. Rani. (2010). "Kontribusi PAD Dalam APBD sebagai Indikator Keberhasilan Penyelenggaraan Otonomi Daerah", Jurnal Ilmu Hukum KANUN 51 (12) August. p. 235. 
the laws and regulations that are above them. The 1945 Indonesian Constitution as the basis of the state clearly states what human rights principles must be fulfilled, therefore the formation of a regional regulation must not conflict with existing human rights values. The movement to eradicate poverty and create a just and prosperous society will never materialize if the mindset of the government apparatus has not changed, they do not want to know that human rights issues are completely focused on the success of the government in fulfilling the human rights of citizens. ${ }^{14}$

The frame for providing human rights protection which according to KBBI ${ }^{15}$ defines protection as 1) a place of refugee or 2) things (actions, etc.) to protect, must be a reference for local governments. This includes providing public facilities that are comfortable and have adequate access to people with physical limitations as a form of taking sides for the protection of human rights. ${ }^{16}$ The fulfillment of human rights by local governments should be based on a progressive spirit to side with the wider community and a form of guaranteeing legal protection for the community. In the legal context, this spirit is based on progressive law.

\subsection{Material Model of Local Regulations on Fulfillment of Human Rights}

\subsubsection{The Principles of Composing Content}

According to Van der Vlies, as quoted by Hamid Attamimi and Maria Farida, in general there are two categories of principles for the formation of appropriate legislation (algemene beginselen van behoorlijk regelgeving), namely the formal principle and the material principle. ${ }^{17}$ In principle, the principle of forming laws and regulations is very

14 Andi Akhirah Khairunnisa. (2018). "Penerapan Prinsip-Prinsip Hak Asasi Manusia Dalam Pembentukan Produk Hukum Oleh Pemerintah Daerah". Jurnal Manajemen Pemerintahan 5 (1) June: $65-78$.

15 Dictionary Development Team Center for Language Development and Development. "Kamus Besar Bahasa Indonesia”. Jakarta: Balai Pustaka. p. 526.

16 Didi Tarsidi. "Aksisibilitas Lingkungan Fisik Bagi Penyandang Cacat". The paper was presented at the Focus Discussion Group on draft regulations for the Protection of Persons with Disabilities in Bandung. Cooperation between the Institute of Community Service Padjajaran University with the Secretariat of the House of Representatives of Bandung City. November 22, 2008. p. 2.

17 I.C. Van der Vlies. (2007). “Handboek Wetgeving (Statutory Drafting Handbook)”. Dirjen Peraturan Perundang-Undangan DEPKUMHAM RI, Jakarta. p. 258-303. See also Attamimi, A. Hamid S. "Peranan Keputusan Presiden Republik Indonesia Dalam Penyelenggaraan Pemerintahan Negara". Fakultas Pascasarjana Universitas Indonesia, 1990 and Maria Farida Indrati S. (2007). "Ilmu Perundang-undangan: Proses dan Teknik Pembentukannya. Jilid 2". Yogyakarta: Kanisius 
relevant to the general principles of good administration as follows: ${ }^{18}$ According to Jimly Asshiddiqie19, the formation of a good rule must be based on philosophical, sociological, juridical, political and administrative aspects. and its enforceability must also be reflected philosophically, sociologically, juridically and politically.

Article 6 Paragraph (1) of Law No. 12 of 2011 concerning the Formation of Prevailing Laws determines that the contents of the Local regulation contain the following principles: 20

a. Protection, that is, every Legislation must function to protect the entire community and provide protection of essential human rights;

b. Humanity, namely every statutory regulation must be humane and respect human dignity and must not burden society beyond the capacity of society itself; 21

c. Nationality, that is, each Legislation must reflect the nature and character of the Indonesian nation which is based on deliberation in making decisions;

d. Kinship, that is, each statutory regulation must reflect the principle of deliberation and consensus in every problem solving regulated in the statutory regulations;

e. Nationality, namely each Legislation is part of the national legal system based on Pancasila or certain areas/ regions, in accordance with the type of Legislation;

f. Unity in unity, that is, every planning, preparation and preparation as well as the contents of the Legislation must take into account the diversity of the population, religion, ethnicity and group, especially concerning sensitive issues in the life of the community, nation and state;

18 Ateng Syafrudin. (1994). “Asas-asas Pemerintahan Yang Layak Pegangan Bagi Pengabdian Kepala Daerah, dalam Himpunan Makalah Asas-asas Umum Pemerintahan Yang Baik (A.A.U.P.B), Constituent: Paulus Effendie Lotulung. Bandung: Citra Aditya Bakti. p. 38-39.

19 Jimly Asshiddiqie. (2006). "Perihal Undang-Undang”. Jakarta: Konstitusi Press. p. 243-244.

20 Modul 1. (2007). "Technical Training on The Preparation of Sun Legislation (Legal Drafting)". Jakarta: Depdagri-LAN

21 Fence M. Wantu dan Moh. Taufik Zulfikar Sarson. (2020). Legal Protection of Women as Victim of Domestic Violence. Indonesian Journal of Advocacy and Legal Services, 1 (2), 243-258. p. 251 
g. Equitable justice, that is, every Legislation must reflect justice for every citizen without exception;

h. Equal position in law and government, that is, each Legislation, the content of which cannot contain things that are discriminatory in nature;

i. Legal order and certainty; namely every Legislation must be able to create legal certainty and order in society;

j. Balance, harmony, and harmony, that is, each Legislation containing material or its contents must reflect the balance, harmony and harmony between the interests of individuals and society, as well as the nation and state.

The principle of compiling the content of the Regional Regulation on the Fulfillment of Human Rights is the foundation for the formation which also covers and functions as a bridge of legal ideals (rechtsidee) which means that in essence law is a rule of behavior of society which is rooted in the ideas, feelings, initiative, creativity, and thoughts of society itself. So the ideals of law are ideas, initiative, creativity, and thoughts regarding law or the perception of the meaning of law. B. Arief Sidharta 22 explained that the ideals of Pancasila law, which are rooted in the Pancasila view of life, will automatically reflect the goals of the state and the basic values formally included in the Preamble, particularly in the formulation of the five philosophical principles of the state, and further elaborated in articles The Body of the 1945 Constitution. The goal of a state is realized by the administration of government by the government. The ideals of Pancasila law must be the guiding star of the material on the contents of the Regional Regulation on Fulfillment of Human Rights to be formed.

In addition to referring philosophically to legal ideals, Regional Regulations on the Fulfillment of Human Rights can be said to have a sociological basis if their provisions are in accordance with general beliefs or public legal awareness. This is in line with the Sociological Jurisprudence school which views law as something that grows in the midst of the people themselves, which changes according to the development of time,

22 B. Arief Sidharta. (2010). "Ilmu Hukum Indonesia”. Bandung: Fakultas Hukum Universitas Katolik Parahyangan. p. 85. 
space and nation. Furthermore, on this matter, Mochtar Kusumaatmadja stated ${ }^{23}$, as follows: "Good law is the law in accordance with the living law in society, which of course is also appropriate or a reflection of the values prevailing in that society".

According to Syaukani and Thohari24, if the law is built on a foundation that is not in accordance with the spiritual structure of society, it is certain that the community's resistance to the law will be very strong. Hart ${ }^{25}$ argues that the existence of a legal system is a social phenomenon that always presents two aspects, which we must pay attention to so that our review of it becomes realistic. These aspects include attitudes and behaviors in the form of recognition of regulations as well as attitudes and behaviors that are simpler in the form of mere obedience or acceptance in silence. Because the recognition that is manifested in attitudes and behavior means that a rule of law can be accepted by society and has reached its complete form in the sociological aspect, because basically according to Gilissen and Gorle26, the source of primary law is the habit of community law.

Then juridically, the Regional Regulation on Fulfillment of Human Rights will observe the following laws and regulations:

a. Article 18 paragraph (6) of the 1945 Constitution of the Republic of Indonesia;

b. Law Number 39 of 1999 concerning Human Rights (State Gazette of the Republic of Indonesia of 1999 Number 165, Supplement to the State Gazette of the Republic of Indonesia Number 3886);

c. Law Number 23 of 2002 concerning Child Protection;

d. Law Number 28 of 2002 concerning Buildings;

e. Law Number 13 of 2003 concerning Manpower;

f. Law Number 20 of 2003 concerning the National Education System;

g. Law Number 11 of 2009 concerning Social Welfare;

23 Mochtar Kusumaatmadja. (1986). "Hukum, Masyarakat dan Pembinaan Hukum Nasional”. Bandung: Binacipta. p. 5.

24 Imam Syaukani and Ahsin Thohari. (2008). "Dasar-Dasar Politik Hukum". Jakarta: Raja Grafindo Persada. p. 25.

25 H.L.A. Hart. (2009). "Konsep Hukum (The Concept Of Law)". Bandung: Nusamedia. p.311.

26 John Gilissen and Fritz Gorle. (2007). "Historische Inleiding Tot Het Recht or Sejarah Hukum translated by Freddy Tengker. Bandung: PT Refika Aditama. p. 23. 
h. Law Number 22 of 2009 concerning Road Traffic and Transportation;

i. Law Number 25 of 2009 concerning Public Services;

j. Law Number 36 of 2009 concerning Health;

k. Law Number 23 of 2014 concerning Regional Government;

l. Law Number 12 Year 2011 concerning the Establishment of Legislation;

m. Law Number 16 of 2011 concerning Legal Aid;

n. Law Number 8 of 2016 concerning Persons with Disabilities;

o. Government Regulation Number 43 of 1998 concerning Efforts to Improve Social Welfare of Persons with Disabilities;

p. Government Regulation Number 36 of 2005 concerning Implementation Regulations of Law Number 28 of 2002 concerning Buildings; and

q. Regulation of the Minister of Home Affairs Number 1 of 2014 concerning the Formation of Regional Legal Products.

\subsubsection{Load Material Model}

Since entering the world of legal thought, Satjipto Rahardjo has been slowly and steadily thinking about, discussing, and understanding law in context.27 Before initiating progressive law, he had long struggled with and taught law to his students. According to his confession in his speech ending his professorship, he also once believed that written law constitutes law, although in that belief there are concerns as quoted below: As part of the prevailing legal education system, I also helped assure students that law was a system of rules that is structured logically, that law creates order, legal certainty and so on. Even so, it turns out that I cannot betray what is in my heart, which is always looking for and wanting to see something more natural than artificial, or more meaningful than stopping at the positive. 28

He brought up the idea of progressive law as a criticism of the praxis of Indonesian law enforcement. The article "Indonesia Needs Progressive Justice" published in the Kompas Daily in 2002 was the trigger for the birth of the idea of progressive law. As

27 Khudzaifah Dimyati. (2010). "Teorisasi Hukum, Studi tentang Perkembangan Pemikiran Hukum Di Indonesia 1945-1990". Yogyakarta: Genta Publishing. p. 182.

28 Satjipto Rahardjo. (2000). "Mengajarkan Keteraturan Menemukan Ketidakteraturan". The speech ended his tenure as Permanent Professor at the Faculty of Law, Diponegoro University. Semarang. P. 2 
an idea, Progressive Law $^{29}$ considers that law should not assume that its work is finished with the creed of "rationality above all", but it is happiness that should be placed above all. Law administrators in this country should always feel anxious if the law cannot make the people happy. ${ }^{30}$ In a broader context, Indonesia as a rule of law must also be able to make its people happy. Furthermore, Satjipto Rahardjo stated "So running an Indonesian constitutional state is carrying out state activities that have a conscience, so that every actor in a state position is obliged to find out what concerns exist with the state (the conscience of the state) inherent in the duties and work they carry out. 31 " Progressive law adheres to a pro-justice ideology and pro-people law. ${ }^{32}$

The assumptions that underlie the progressiveness of the law are: first, law exists for humans and not for itself; both laws are always in the status of law in the making and are not final; the third law is a human moral institution, and not technology which has no conscience. ${ }^{33}$ Taking into account the things that underlie legal progressivism above, in principle, the existence of the law is actually to protect humans as users of the law. Laws are made for humans, so the laws that are made must be human laws.

On the basis of this assumption, the criteria for progressive law are: first, it has a big goal in the form of human welfare and happiness; second, contains a very strong human moral content; third, progressive law is a law that liberates covering a very broad dimension that does not only move in the realm of practice, but also theory; fourth, it is critical and functional, because progressive laws constantly see the existing deficiencies and find ways to improve them.

Progressive law places human interests and needs as its point of orientation, so it must be sensitive to problems that arise in its relationship with humans. One of the crucial problems in social relations is the shackling of humans in oppressive

29 The idea of progressive law first emerged in 2002 through an article written by Satjipto Rahardjo on kompas daily with the title "Indonesia Membutuhkan Penegakan Hukum Progresif". June 15, 2002.

30 Satjipto Rahardjo. "Membedah Hukum Progresif'. Jakarta: Penerbit Buku Kompas. P. 20

31 Satjipto Rahardjo. (2009). "Negara Hukum Yang Membahagiakan Rakyatnya". Yogyakarta: Genta Publishing. p. 93.

32 Satjipto rahardjo. (2009). "Hukum Progresif sebuah Sintesa Hukum Indonesia". Yogyakarta: Genta Publishing. p. 6.

33 Op. cit. Hukum Progresif. P. 8 
structures, both politically, economically and socio-culture. In the context of this shackling, progressive law must appear as an emancipatory (liberating) institution.

The character of progressive law which requires the presence of law to be associated with empowerment as its social goal, causes progressive law to be close to social engineering of Roscoe Pound. ${ }^{34}$ Quoting Satjipto Rahardjo's opinion, he said that: "the effort to reform the legal system through and using the concept of progressive law is very relevant in terms of its character that (a) law is for humans and not just for the law itself, (b) law is not an institutional institution. which is absolute, autonomous and final, but is a dynamic reality that continues to move, change, develop itself in line with changes in human life and (c) progressive law is basically pro-justice, propeople, as well as anti-discrimination and anti-anarchic law. "35

The idea of progressive law provides a breath of fresh air in efforts to enforce a more humane law in Indonesia. As a criticism of law enforcement efforts, progressive law has been compiled in various writings of Satjipto Rahardjo. Extracting from these various writings, Shidarta presents ten points of a series of key words that form the common thread of Satjipto Rahardjo's progressive legal thinking. These key words are as follows: 36

a. Progressive law is for humans, not humans for laws.

b. The progressive law must be pro-people and pro-justice.

c. Progressive law aims to bring humans to prosperity and happiness.

d. Progressive law is always in the process of becoming (law as a process, law in the making).

e. Progressive law emphasizes the good life as the basis of good law.

f. Progressive law has a type of responsive law.

g. Progressive law promotes a public role.

34 Roscoe Pound in Bernard L. Ask and friends. (2010). "Teori Hukum Strategi Tertib Manusia Lintas Ruang dan Generasi"., Stating that in order to achieve justice, progressive steps are needed, namely to enable the law to organize changes. Yogyakarta: Genta Publishing. p. 155.

35 Satjipto Raharjo quoted by Yusriyadi. (2010). "Tebaran Pemikiran Kritis Hukum dan Masyarakat". Malang: Surya Pena Gemilang. P. 37.

36 Shidarta. (2013). "Pendekatan Hukum Progresif Dalam Mencairkan Kebekuan Produk Legislasi, Tulisan Dalam Buku Dekonstruksi dan Gerakan Pemikiran Hukum Progresif'. Yogyakarta: Thafa Media. P. 24-26. 
h. Progressive law builds a rule of law with a conscience.

i. Progressive laws are enforced with spiritual intelligence.

j. The progressive law breaks down, replaces and sets free.

Based on the ten key words about progressive law that has been described by Shidarta above, basically Satjipto Rahardjo has stated: "If it may be summarized, progressive law is actually simple, namely to carry out liberation, both in the way of thinking and acting in law, so as to be able to leave the law alone. it just flows and completes its task of serving humanity and humanity ". 37 Basically, progressive legal theory concentrates on the aspect of law enforcement. ${ }^{38}$ However, it can also be applied to aspects of legal formation.

This progressive legal frame can be used as a basis in the construction of a material model for the content of regional human rights regulations. The material model for the content of the Local regulation on the Fulfillment of Human Rights is based on progressive law which is based on the concept of progressive law that is promoted by Satjipto Rahardjo which is oriented towards the community as the object of the implementation of law that must benefit from the enactment of the law. So that the law is not repressive. 39

The material model for the content of the Local regulation Fulfillment of Human Rights based on progressive law relies on three things, namely: laws and regulations that regulate human rights both vertically and horizontally, the contextual reality of the recognition and protection of human rights found in local communities and

37 Satjipto Rahardjo. (2010). “Penegakan Hukum Progresif”. Jakarta: Kompas. P. 69.

38 Soerjono Soekanto in his book the factors that influence law enforcement conceptualize the core and meaning of law enforcement lies in the activities of aligning the relationship of values described in the rules of steady and spelling out and attitude of action as a series of elaboration of the value of the final stage, to create, maintain and maintain the peace of social life. He further stated that there are five factors that may affect law enforcement, namely: his own law; law enforcement; facilities or facilities; community; Culture. These five factors are closely related, because they are the essence of law enforcement, also a benchmark rather than the effectiveness of law enforcement. See Soerjono Soekanto. (2005). "Faktor-Faktor yang Mempengaruhi Penegakan Hukum." Jakarta: Raja Grafindo Persada. P. 5-9.

39 Bernard L. Tanya. (2010). "Teori Hukum (Strategi Tertib manusia Lintas Ruang dan Generasi)". Yogyakarta: Genta Publishing. p. 37. 
thirdly for humans and humanity. Systematically, the division of chapters containing the content in it consists of: general provisions; principles and objectives; type of human rights; human rights recognition; protection of human rights; fulfillment of human rights; community participation; guidance and supervision; funding and closing provisions.

\section{Conclusion}

Based on the previous section, it can be concluded that the material model for the content of the Local regulation on the Fulfillment of Human Rights based on progressive law rests on three things, namely: laws and regulations that regulate human rights both vertically and horizontally, the contextual reality of human rights recognition and protection contained in the local community and the third is the value of the service of law for humans and humanity. Systematically, the division of chapters containing the content in it consists of: general provisions; principles and objectives; type of human rights; human rights recognition; protection of human rights; fulfilment of human rights; community participation; guidance and supervision; funding and closing provisions.

\section{References}

\section{Books:}

Ateng Syafrudin, (1994). Asas-asas Pemerintahan Yang Layak Pegangan Bagi Pengabdian Kepala Daerah, dalam Himpunan Makalah Asas-asas Umum Pemerintahan Yang Baik (A.A.U.P.B), penyusun: Paulus Effendie Lotulung, Bandung: Citra Aditya Bakti.

Attamimi, A. Hamid S. (1990). Peranan Keputusan Presiden Republik Indonesia Dalam Penyelenggaraan Pemerintahan Negara, Jakarta: Fakultas Pascasarjana Universitas Indonesia.

B. Arief Sidharta. (2010). Ilmu Hukum Indonesia. Bandung: Fakultas Hukum Universitas Katolik Parahyangan.

Bernard L. Tanya. (2010). Teori Hukum (Strategi Tertib manusia Lintas Ruang dan Generasi). Yogyakarta: Genta Publishing.

Brian Z. Tamanaha (2006), A General Jurisprudence of Law and Society, Oxford University Press.

Didi Tarsidi. (2008). Aksisibilitas Lingkungan Fisik Bagi Penyandang Cacat. Makalah disajikan pada Focus Discussion Group tentang Draft Ralocal regulation 
Pelindungan Penyandang Cacat Kota Bandung. Kerjasama antara Lembaga Pengabdian kepada Masyarakat UNPAD dengan Sekretariat DPRD Kota Bandung, 22 Nopember.

FX. Adji Samekto (2012), Ilmu Hukum dalam Perkembangan Pemikiran Menuju PostModernisme, Lampung: Indept Publishing.

H.L.A. Hart. (2009). Konsep Hukum (The Concept Of Law) Terjemahan Raisul Muttaqien, Bandung: Nusamedia.

I.C. Van der Vlies, (2007). Handboek Wetgeving (Buku Pegangan Perancang Peraturan Perundang-Undangan), Jakarta: Dirjen Peraturan Perundang-Undangan DEPKUMHAM RI.

Imam Syaukani dan Ahsin Thohari, (2008). Dasar-Dasar Politik Hukum. Jakarta: Raja Grafindo Persada.

Jimly Asshiddiqie. (2006). Perihal Undang-Undang, Jakarta: Konstitusi Press.

John Gilissen dan Fritz Gorle. (2007). Historische Inleiding Tot Het Recht, atau Sejarah Hukum Terj. Freddy Tengker. Bandung: PT Refika Aditama.

Khudzaifah Dimyati, (2010). Teorisasi Hukum, Studi tentang Perkembangan Pemikiran Hukum Di Indonesia 1945-1990, Genta Publishing, Yogyakarta.

Maria Farida Indrati S. (2007). Ilmu Perundang-undangan: Proses dan Teknik Pembentukannya. Jld 2. Yogyakarta: Kanisius.

Mochtar Kusumaatmadja, (1986). Hukum, Masyarakat dan Pembinaan Hukum Nasional, Bandung: Binacipta.

Satjipto Rahardjo, (2008). Membedah Hukum Progresif, Jakarta: Penerbit Buku Kompas.

Satjipto Rahardjo, (2009). Negara Hukum Yang Membahagiakan Rakyatnya, Yogyakarta: Genta Publishing-cet 2.

Satjipto Rahardjo, (2010). Penegakan Hukum Progresif, Jakarta: Kompas.

Satjipto Rahardjo. (2000). Mengajarkan Keteraturan Menemukan Ketidakteraturan, Pidato mengakhiri Jabatan sebagai Guru Besar Tetap pada FH Undip, Semaran.

Satjipto Rahardjo. (2009). "Hukum Progresif sebuah Sintesa Hukum Indonesia,. Yogyakarta:Genta Publishing.

Shidarta, (2013). Pendekatan Hukum Progresif Dalam Mencairkan Kebekuan Produk Legislasi, Tulisan Dalam Buku Dekonstruksi dan Gerakan Pemikiran Hukum Progresif, Yogyakarta: Thafa Media. 
Soerjono Soekanto, (2005). Faktor-Faktor yang Mempengaruhi Penegakan Hukum, Jakarta: Raja Grafindo Persada.

Tim Penyusun, (1988). Kamus Pusat Pembinaan dan Pengembangan Bahasa, Kamus Besar Bahasa Indonesia, Jakarta: Balai Pustaka.

Tim Penyusun, (2015) Majelis Umum PBB, Role of local government in the promotion and protection of human rights-Final report of the Human Rights Advisory Committee, A/HRC/30/49, 7 Agustus.

Tim Penyusun, Modul 1, (2007). Diklat Teknis Penyusunan Peraturan PerundangUndangan (Legal Drafting) Jakarta: Depdagri-LAN.

Yusriyadi. (2010). Tebaran Pemikiran Kritis Hukum dan Masyarakat. Malang: Surya Pena Gemilang.

\section{Journal:}

Achir Nuvazria. (2020). "Anotasi Normatif Terhadap Peraturan Daerah Tentang Transparansi". Jambura Law Review, JALREV 2 (1): 83-100.

Al Khanif, dkk, (2019). Kajian Tentang Model Rencana Aksi Daerah Hak Asasi Manusia (RADHAM) Kabupaten Bondowoso Tahun 2018, Jurnal Hukum \& Pembangunan 49 No. 2: 425-442.

Andi Akhirah Khairunnisa, (2018). Penerapan Prinsip-Prinsip Hak Asasi Manusia Dalam Pembentukan Produk Hukum Oleh Pemerintah Daerah, Jurnal MP (Manajemen Pemerintahan) Vol. 5, No. 1/ Juni.

Faisal A. Rani, (2010). “Kontribusi PAD Dalam APBD sebagai Indikator Keberhasilan Penyelenggaraan Otonomi Daerah", Jurnal Ilmu Hukum KANUN, Nomor 51 Tahun XII, Edisi Agustus.

Fence M. Wantu dan Moh. Taufik Zulfikar Sarson. (2020). Legal Protection of Women as Victim of Domestic Violence. Indonesian Journal of Advocacy and Legal Services, 1 (2): 243-258

Frichy Ndaumanu, (2018). Kebijakan Pemerintah Daerah Terhadap Upaya Perlindungan Dan Penghormatan Masyarakat Hukum Adat Di Kabupaten Alor Provinsi Nusa Tenggara Timur, Jurnal HAM Vol. 9 No. 1, Juli: 37-49.

Novendri M. Nggilu and Fence M. Wantu. (2020). Menapaki Jalan Konstitusional Menuju Zaken Cabinet: Ikhtiar Mewujudkan Pemerintah Berkualitas Konstitusi. Jurnal Hukum Samudra Keadilan, 15(1): 126-140. 


\section{Internet:}

Human Rights National Committee. (ed. January 8, 2016). Retrieved from https://www.komnasham.go.id/index.php/news/2016/1/8/245/mendorong -kota-ramah-ham-di-indonesia.html Accessed February 10, 2020. 